\title{
Fluorescein Diacetate (FDA): Measure of Total Microbial Activity and as Indicator of Soil Quality
}

\author{
P. N. Patle $^{1 *}$, N. P. Navnage ${ }^{2}$ and P. K. Barange ${ }^{3}$ \\ ${ }^{1}$ Department of Soil Science and Agricultural Chemistry, Dr. Panjabrao Deshmukh Krishi \\ Vidyapeeth, Akola 444104 (M.S.), India \\ ${ }^{2}$ Department of Soil Science and Agricultural Chemistry, Indira Gandhi Krishi \\ Vishwavidyalaya, Raipur 492012 (C.G.), India \\ ${ }^{3}$ Department of Soil Science and Agricultural Chemistry, Mahatma Fule Krishi Vidyapeeth, \\ Rahuri 413722 (M.S.), India \\ *Corresponding author
}

\section{A B S T R A C T}

Soil is crucial to life on earth. Enormous agriculture practices may emerge a numerous problem like reduction in soil fertility, erosion, ground water contamination which has direct impact on the soil health. It is indispensable to study overall microbial activity potential and different changes in soil biological properties for maintaining soil health and

\begin{tabular}{|l|}
\hline Key w or d s \\
Fluorescein \\
$\begin{array}{l}\text { Diacetate (FDA), } \\
\text { role, microbial } \\
\text { indicator, methods }\end{array}$ \\
\hline Article Info \\
\hline $\begin{array}{l}\text { Accepted: } \\
18 \text { May } 2018 \\
\text { Available Online: } \\
\text { 10 June } 2018\end{array}$ \\
\hline \hline
\end{tabular}
its quality. Soil enzyme is essential to play important role in maintaining soil health and to asses it quality. The fluorescein diacetate (FDA) hydrolysis is one of the important to measures the enzyme activity of microbial populations and can provide an assessment of microbial activity in soil. Assessment of Hydrolysis of fluorescein diacetate [3', 6'diacetylfluorescein (FDA)] has been suggested as prospective method for determination of total microbial activity because it includes several enzyme classes including lipases, esterases, and proteases. Spectrophotometric determination of the hydrolysis of fluorescein diacetate (FDA) was shown to be a simple, sensitive, and rapid method for determining microbial activity in soil. The assessment of FDA in soil is done by incubating the soil sample with buffer and FDA for $1-2$ hours. The amount of fluorescent color formation during the incubation is indicative of the enzymatic activity of the microbial community in the sample. The intensity of the color will be measured by a spectrophotometer and compared to a standard curve to determine the relative microbial activity in your sample. The main intendment of this review paper to define the role of FDA hydrolysis in soil environment as well as method to estimate FDA enzyme activity in soil. Paper also illustrate that FDA enzyme activity serves as microbial indicator and measure of total microbial activity to asses soil health and is quality.

\section{Introduction}

Soil is a dynamic natural body, non-renewable resource, composed of mineral and organic solids, gases, liquids, and living organism which serves as medium for plant growth and monitoring its fertility is an important objective in the sustainable development of 
agro-ecosystems. The quality of soil depends in part on its natural composition, and also on the changes caused by human use and management (Pierce and Larson, 1993). There is needing to assessment of soil quality for maximize the growth and productivity of crop. Strategies based on biological indicators would be a suitable tool to evaluate the sustainability of the soil ecosystem. Studies of soil enzymatic activity assay are best indicator to measure the ecosystem status and quality of soils.

Soil enzymes are the mediators and catalysts of important soil functions that include: decomposition of organic inputs; transformation of native soil organic matter; release of inorganic nutrients for plant growth; N2 fixation; nitrification; gentrification; and detoxification of xenobiotics (Dick, 1997). In addition, soil enzymes have a crucial role in $\mathrm{C}$ ( $\beta$-glycosidase and $\beta$-galactosidase), $\mathrm{N}$ (unease), $\mathrm{P}$ (phosphates), and $\mathrm{S}$ (sulphatase) cycle (Karaca et al., 2011).

There are lots of enzymes in the soil environment, serves as biological indicator of soil. Among all enzymes in soil environment, the fluorescein diacetate hydrolysis enzyme activity is commonly used as an indicator of biological activity in soils (Burns 1978). Fluorescein diacetate (FDA) hydrolysis is most accepted as an accurate and simple method for measuring total microbial activity in a range of environmental samples, including soils.

The enzymes responsible for FDA hydrolysis are plentiful in the soil environment. Nonspecific esterases, proteases and lipases, which have been shown to hydrolyse FDA, are involved in the decomposition of many types of tissue. The ability to hydrolyse FDA thus seems widespread, especially among the major decomposers, bacteria and fungi (Schnürer and Rosswall, 1982). Generally more than
$90 \%$ of the energy flow in a soil system passes through microbial decomposers; therefore an assay which measures microbial decomposer activity will provide a good estimate of total microbial activity.

The FDA method was also shown to correlate well with some of the most accurate measures of microbial biomass such as ATP content and cell density studies (Stubberfield and Shaw, 1990).

The use of fluorescein esters as a measure of enzyme activity was first noted by Kramer and Guilbault (1963) where a simple procedure was described for the assay of lipase activity in the presence of other esterases. Swisher and Carroll (1980). Demonstrated that the amount of fluorescein produced by the hydrolysis of fluorescein diacetate (FDA) was directly proportional to the microbial population growing on Douglas Fir foliage and a standardized method was developed. This method was later evaluated by Schnürer and Rosswall (1982) who used FDA hydrolysis to determine total microbial activity in soil and straw litter as well as cell density in pure microbial cultures.

Determination of FDA hydrolysis is done by incubating the soil sample with buffer and FDA for $1-2$ hours. The amount of fluorescent color formation during the incubation is indicative of the enzymatic activity of the microbial community in the sample. The intensity of the color will be measured by a spectrophotometer at wavelength of $490 \mathrm{~nm}$ and compared to a standard curve to determine the relative microbial activity in your sample.

Thus FDA hydrolysis enzyme in the soil is very important as it may giveindications of the potential of the soil to support biochemical processes, which areessential for maintaining soil fertility as well as soil health. 
Methodology for assessment of FDA hydrolysis in soil, plant sample

\section{Reagent}

\section{$60 \mathrm{mM}$ potassium phosphate buffer pH 7.6}

8.7 g K2HPO4 (Riedel-de Haën, SigmaAldrich Co. Ltd., Analar) and 1.3 g KH2PO4 (Merck, BDH Analar) were dissolved in approximately $800 \mathrm{ml}$ deionised water. The contents were made up to 11 with deionised water. The buffer was stored in the fridge $\left(4^{\circ} \mathrm{C}\right)$ and $\mathrm{pH}$ checked on day of use.

\section{2:1 chloroform/methanol}

$666 \mathrm{ml}$ chloroform (Fisher Scientific UK Limited, analytical grade) was added to a 11 volumetric flask. The flask was made up to 11 with methanol (Fisher Scientific UK Limited, analytical grade) and the contents mixed thoroughly.

\section{$1000 \mu \mathrm{g}$ FDA ml -1 stock solution}

$0.1 \mathrm{~g}$ fluorescein diacetate (3' 6'-diacetylfluorescein., Sigma-Aldrich Co. Ltd.) was dissolved in approximately $80 \mathrm{ml}$ of acetone (Fisher Scientific UK Limited, analytical grade) and the contents of the flask made up to $100 \mathrm{ml}$ with acetone. The solution was stored at $-20^{\circ} \mathrm{C}$.

\section{$2000 \mu \mathrm{g}$ fluorescein $\mathrm{ml}-1$ stock solution}

$0.2265 \mathrm{~g}$ fluorescein sodium salt (Merck, $\mathrm{BDH}$ Analar) was dissolved in approximately $80 \mathrm{ml}$ of $60 \mathrm{mM}$ potassium phosphate buffer pH 7.6 and the contents made up to $100 \mathrm{ml}$ with buffer.

\section{$20 \mu \mathrm{g}$ fluorescein $\mathrm{ml}-1$ standard solution}

$1 \mathrm{ml}$ of $2000 \mu \mathrm{g}$ fluorescein $\mathrm{ml}-1$ stock solution was added to a $100 \mathrm{ml}$ volumetric flask and the contents made up to the mark with $60 \mathrm{mM}$ potassium phosphate buffer $\mathrm{pH}$ 7.6. $1-5 \mu \mathrm{g} \mathrm{ml} \mathrm{-1} \mathrm{standards} \mathrm{were} \mathrm{prepared}$ from this standard solution by appropriate dilution in $60 \mathrm{mM}$ potassium phosphate buffer $\mathrm{pH}$ 7.6.

\section{Procedure}

$2 \mathrm{~g}$ soil (fresh weight, sieved $<2 \mathrm{~mm}$ ) was placed in a $50 \mathrm{ml}$ conical flask and $15 \mathrm{ml}$ of $60 \mathrm{mM}$ potassium phosphate buffer $\mathrm{pH} 7.6$ added. $0.2 \mathrm{ml} 1000 \mu \mathrm{g}$ FDA ml -1 stock solution was added to start the reaction. Blanks were prepared without the addition of the FDA substrate along with a suitable number of sample replicates. The flasks were stoppered and the contents shaken by hand.

The flasks were then placed in an orbital incubator (Gallenkamp Orbital Incubator, 100 rev min -1 ) at $30^{\circ} \mathrm{C}$ for $20 \mathrm{~min}$. Once removed from the incubator, $15 \mathrm{ml}$ of chloroform/methanol $(2: 1 \mathrm{v} / \mathrm{v})$ was added immediately to terminate the reaction. Stoppers were replaced on the flasks and the contents shaken thoroughly by hand. The contents of the conical flasks were then transferred to $50 \mathrm{ml}$ centrifuge tubes and centrifuged at 2000 rev min-1 for approximately $3 \mathrm{~min}$. The supernatant from each sample was then filtered (Whatman, No 2) into $50 \mathrm{ml}$ conical flasks and the filtrates measured at $490 \mathrm{~nm}$ on a spectrophotometer (Hitachi U - 1100 spectrophotometer).

The concentration of fluorescein released during the assay was calculated using the calibration graph produced from $0-5 \mu \mathrm{g}$ fluorescein ml-1 standards which were prepared from a $20 \mu \mathrm{g}$ fluorescein ml-1 standard solution. The $0 \mu \mathrm{g} \mathrm{ml}-1$ fluorescein standard was used to zero the spectrophotometer before each set of blanks and samples were read. (Adam, G. et al., 2001) 
Fig.1 The fluorescent yellow color is produced as microbial enzymatic activity hydrolyzes FDA (colorless) into fluorescein (yellow) and $0-5 \mu \mathrm{g}$ fluorescein ml-1 standards which were prepared from a $20 \mu \mathrm{g}$ fluorescein ml-1 standard solution

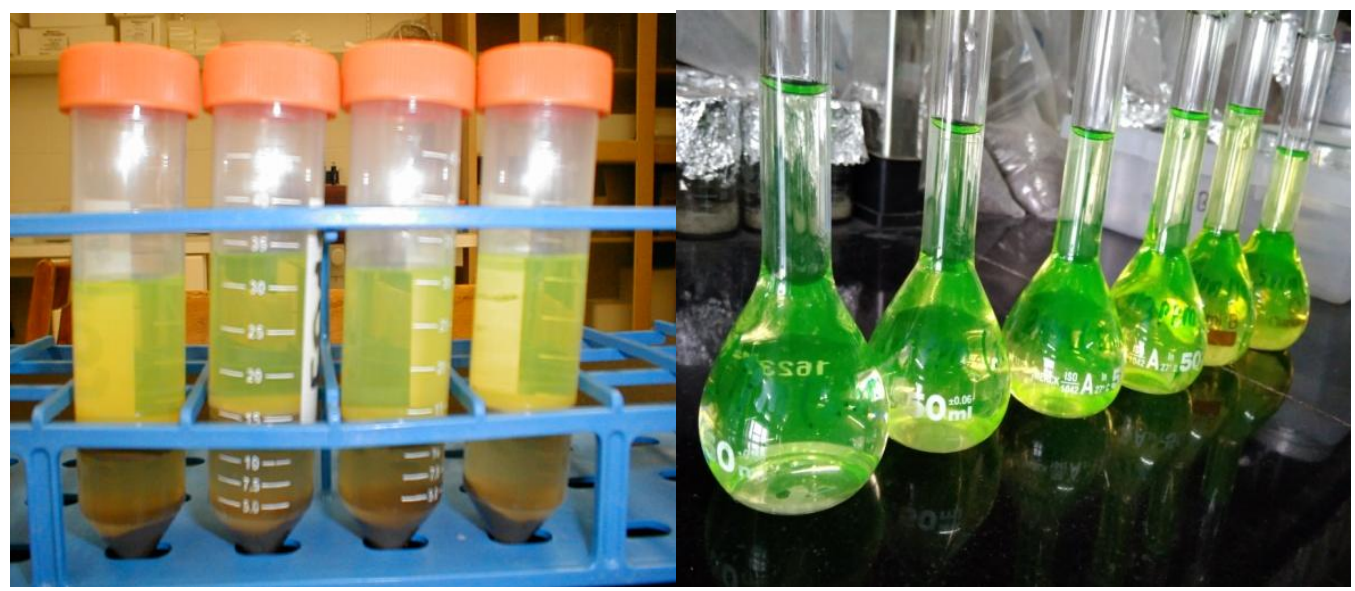

Soil is a dynamic natural body and important part of terrestrial compartment, and supports all terrestrial life forms. Thus, without proper soil management practices, numerous problems may arise, like reduction of soil Fertility, erosion, groundwater contamination, insufficient water holding capacity and loss of Biodiversity. Assessment of soil quality by using soil microbial indicators is very sensitive approach which is responds quickly to environmental alterations. There are several biological soil properties that can be used as soil quality indicators, alone or in combination with other chemical or physical properties.

Among different soil indicators, FDA hydrolysis enzyme activity is one of the most adequate, important and one of the most sensitive bioindicators, relating to soil quality and fertility. FDA hydrolysis is proposed as the best indicator of the microbiological redox-systems, and could be considered as good and adequate parameter of microbial oxidative activities in soil. Exploiting the usefulness of FDA hydrolysis enzyme activity in assessment of soil quality and health is key to best soil quality indicator in agriculture system. Therefore understanding the role of
FDA hydrolysis activity in soil environment and study of different methodologies for their assessment has large potential to use as soil quality indicator.

\section{References}

Adam, G. and H. Duncan. 2001. Development of a sensitive and rapid method for the measurement of total microbial activity using fluorescein diacetate (FDA) in a range of soils. Soil Biol. Biochem. 33:943-951.

Burns RG (1978) Enzyme activity in soil: some theoretical and practical considerations. In: Bum RG (ed) Soil enzymes. Academic, London, pp 295340

Dick RP (1997) Soil enzyme activities as integrative indicators of soil health. In: Pankhurst CE, Doube BM, Gupta VVSR (eds) Biological indicators of soil health. CABI, Wellingford, pp 121156.

Karaca, A., Cema, C.C., Turgay, O.C., Kizilkaya, R. (2011): Soil Enzymes as Indicator of Soil Quality. - In: Shukla, Varma, G. A. (eds.) Soil Enzymology, 
Soil Biology 22, Springer-Verlag Berlin Heidelberg USA.

Kramer, D. N., Guilbault, G. G., 1963. A substrate for the fluorimetric determination of lipase activity. Analytical Chemistry 35, 588-589.

Pierce, F.J., and Larson, W.E. (1993): Developing Criteria to Evaluate Sustainable Land Management. - In: Kimble, J.M. (ed.) Proceeding of the VIII International Soil Management Workshop Utilization of Soil Survey Information for Sustainable Land use Sacramento, CA.
Schnurer, J. and T. Rosswall. 1982. Fluorescein diacetate hydrolysis as a measure of total microbial activity in soil and litter. Appl. Environ. Microbiol. 43:1256-1261.

Stubberfield, L. C. F., Shaw, P. J. A., 1990. A comparison of tetrazolium reduction and FDA hydrolysis with other measurements of microbial activity. Journal of Microbiological Methods 12, 151-162.

Swisher, R., Carroll, G. C., 1980. Fluorescein diacetate hydrolysis as an estimator of microbial biomass on coniferous needle surfaces. Microbial Ecology 6, 217-226

\section{How to cite this article:}

Patle P. N., N. P. Navnage and Barange P. K. 2018. Fluorescein Diacetate (FDA): Measure of Total Microbial Activity and as Indicator of Soil Quality. Int.J.Curr.Microbiol.App.Sci. 7(06): 2103-2107. doi: https://doi.org/10.20546/ijcmas.2018.706.249 